\section{Congress on Spectroscopy}

A FIFTH spectroscopy conference will be held at the George Eastman Research Laboratories of the Massachusetts Institute of Technology on July 19-21, repeating to a considerable extent the type of conferences held during the past four summers. A programme of papers and discussions is being prepared on analysis of materials by the emission spectrum, absorption spectro-photometry, photographic photometry, biological and chemical effects of spectral radiation, and industrial applications of spectroscopy. The usual summer courses on practical and applied spectroscopy will be offered at the Institute between June 14 and July 24. Further information can be obtained from Prof. G. R. Harrison, Department of Physics, Massachusetts Institute of Technology, Cambridge, Massachusetts.

\section{The Partial Transit of Mercury on May II}

ON May 1 I next, a partial transit of the planet Mercury across a narrow segment of the sun's disk occurs between $8^{\mathrm{h}} 31^{\mathrm{m}}$ and $9^{\mathrm{h}} 3 \mathrm{c}^{\mathrm{m}}$ U.T., the maximum ingress being only $7 \cdot 3^{\prime \prime}$. The partial transit will not be visible from Great Britain but can be seen generally from over southern Asia, the Philippine Islands, Western Australia, the Indian Ocean and Central and Southern Africa. The "Nautical Almanac" for 1937 on p. 519 gives the local circumstances for several places from which the partial transit may be observed. Dr. A. C. D. Crommelin has pointed out that it is important for observers in the southern hemisphere to watch for the appearance of any are of sunlight around the limb of the planet (projected on the sun's limb) due to a Mercurian atmosphere. such an arc has been observed in the case of Venus but never with certainty in the case of Mercury. Although this partial transit is not visible from Great Britain, Dr. Crommelin suggests further that spectroscopists in Great Britain may see Mercury projected on the chromosphere; the nearest approach to the sun is at $9^{\mathrm{h}} 0^{\mathrm{m}}$ (Summer Time $10^{\mathrm{h}} 0^{\mathrm{m}}$ ) at position angle $154^{\circ}$ from the north point.

\section{Announcements}

Sir Frederick Gowland Hopkins has been awarded the Harben Gold Medal of the Royal Institute of Public Health. The Medal is awarded triennially, under a trust created by the late Sir Henry Harben, to the person, irrespective of nationality, who, in the opinion of the Council of the Royal Institute of Public Health, has rendered the most eminent services to public health. Past recipients of the Medal include: Louis Pasteur, John Simon, Max von Pettenkofer, Lister, Koch, Metchnikoff, Behring, Roux, Ronald Ross, Sir Charles Sherrington, and Kitasato.

THE Council of the British Scientific Instrument Research Association has accepted with regret the resignation of Dr. Harry Moore, who, since the retirement of the late Sir Herbert Jackson, in July 1933, has been the director of research of the Association. The period during which Dr. Moore has been in charge of the Association's research work has been one of great activity and usefulness to the British scientific instrument industry. Dr. Moore's particular knowledge and experience of the research needs of industry will not be lost, as he has accepted an appointment in which he will direct the research work of an industrial corporation. Mr. A. J. Philyot has been appointed to succeed Dr. Moore as director of research.

Dr. E. B. Worthington, demonstrator of zoology in the University of Cambridge, has been appointed director of the Laboratory at Wray Castle on Lake Windermere of the Freshwater Biological Association of the British Empire.

Dr. N. K. Adar will open a discussion, under the auspices of the University of London Animal Welfare Society, on "The Destruction of Sea-Birds by" Oil Waste" in the Chemistry Theatre at University College, London, on May 10 at 5.30. Admission is free.

SIR John RussecL will deliver the thirty-eighth Bedson Club lecture at Armstrong College, Newcastleupon-Tyne, on May 21, at 6.30. The subject of the lecture will be "Chemistry in Modern Food Pro. duction".

THe ninth International Congress for Psychotherapeutics will be held at Copenhagen on October 2-4. The official languages are English, French and German. Further information can be obtained from the president, Prof. C. G. Jung, Küssnacht. Zurich.

AN International Congress is being organized by the International Abolitionist Federation to be held in Paris from May 20-22, when the problem of prostitution will be studied from the legal, medical and moral points of view. Further information can be obtained from the Secretariat of the Federation, 8 rue de l'Hôtel de Ville, Geneva.

THRe fellowships in psychiatry, each of the value of $£ 300$, are offered for half-time work at the London Child Guidance Clinic, 1 Canonbury Place, N.1. Further information can be obtained from the Secretary of the Council, Woburn House, Upper Woburn Place, London, W.C.1.

WE regret that in a short notice of "The Hair in Health and Disease", by Mr. Edward Lawrence, in NATURE of May 1, the statement was incorrectly made that the author was a barber. Mr. Lawrence has been a fellow of the Royal Anthropological Institute and member of the Geologists' Association since 1885. $\mathrm{He}$ is described on the title page of his book as scientific correspondent of the Hairdressers' Weekly Journal and author of "Savage Life and Custom", etc., and his works include, he informs us, "Over 400 contributions on folk lore, antiquarian and other subjects to Hairdressing Fashions and The Hairdressers' Weekly Journal". 